\title{
PENGUJIAN BEBERAPA VARIABEL YANG MENENTUKAN KESUKAAN KONSUMEN MEMBELI BANDENG PRESTO (Chanos Chanos Fork) GRESIK
}

\author{
Matheus Nugroho*) \\ *) Tenaga Pengajar Universitas Yudharta Pasuruan
}

\begin{abstract}
Abstrak
Tujuan penelitian ini untuk menganalisis seberapa besar pengaruh variabel kualitas produk, pelayanan, harga, promosi dan distribusi terhadap kesukaan konsumen dalam membeli produk bandeng presto, dan menentukan pengaruh variabel yang dominan terhadap kesukaan konsumen dalam membeli produk bandeng presto. Dalam penelitian ini menggunakan metode analisis model regresi liniear berganda OLS (Ordinary Least Squares), hasil perhitungan dengan program SPSS. Hasil analisis menunjukkan bahwa besarnya pengaruh variabel terhadap kesukaan konsumen dalam membeli produk bandeng presto adalah kualitas produk sebesar 0,227 , pelayanan $-0,026$, harga 0,144 , promosi 0,090 dan distribusi sebesar 0,264. Pengaruh variabel yang paling dominan terhadap kesukaan konsumen dalam membeli produk bandeng presto adalah distribusi sebesar 0,264 (26,4\%), dan peringkat berikutnya variabel kualitas produk $0,227(22,7 \%)$.
\end{abstract}

Kata kunci: kepuasan pelanggan, distribusi, kualitas produk, harga, promosi dan pelayanan 


\begin{abstract}
The objective of this study to analyze how much influence the variable product quality, service, price, promotion and distribution of consumer preferences in the purchase of products milkfish presto, and determine the dominant influence of variables on consumer preferences in buying products milkfish presto. In this study using the method of analysis of the multiple regression model liniear OLS (Ordinary Least Squares), calculated with SPSS program. The analysis showed that the magnitude of the effect of variables on consumer preferences in buying milkfish presto products are quality products at $0.227,-0.026$ service rates, $0.144,0.090$ promotion and distribution of 0.264 . The most dominant variable influence on consumer preferences in buying products milkfish Presto is a distribution of $0.264(26.4 \%)$, and the next rank variable product quality $0.227(22.7 \%)$.
\end{abstract}

Key words: customer satisfaction, distribution, product quality, price, promotion and service

Salah satu produk perikanan yang sering dikonsumsi oleh masyarakat adalah ikan bandeng. Ikan bandeng merupakan suatu komoditas perikanan yang memiliki rasa cukup enak dan gurih sehingga banyak digemari masyarakat. Selain itu, harganya juga terjangkau oleh segala lapisan masyarakat. Ikan bandeng digolongkan sebagai ikan berprotein tinggi dan berkadar lemak rendah. Pada umumnya ikan bandeng diolah secara tradisional antara lain dengan cara pengasapan, penggaraman, pemindangan dan presto (Susanto, 2010).

Bandeng Presto merupakan makanan yang cukup populer dewasa ini, sehingga sudah dapat ditemui dan cukup laku dijual di pasar-pasar tradisional sampai dengan pasar swalayan. Bandeng Presto dibuat dari bandeng segar utuh, yang diolah dengan cara dibuang isi perut dan insangnya terlebih dahulu, dicuci larutan garam 3\%, direndam larutan bumbu atau larutan garam secukupnya, ditiris, dibungkus daun pisang satu per satu dan selanjutnya dimasak (dikukus) didalam panci bertekanan tinggi (press cooker) selama satu jam. Hasil pemasakan yang telah dingin dapat dikemas untuk dipasarkan lebih lanjut atau langsung digoreng setelah disalut 
adonan putih telur/tepung untuk disajikan (siap disantap) sebagai lauk atau makanan camilan (Co Fish Project, 2004).

Pada tahun 2000 tambak Jawa Timur tercatat seluas 53423 ha atau $15 \%$ dari luas tambak di tanah air (BPS, 2002). Pusat tambak di Jawa Timur terletak di Kabupaten Gresik dengan luas 38,44\% (20535,80 ha) dari luas tambak Jawa Timur, dimana lebih dari $60 \%$ (12321,4 ha) tambak adalah tambak bandeng (BPS Propinsi Jawa Timur, 2003).

Selama sepuluh tahun terakhir (1990-2003) pertumbuhan luas tambak maupun produksinya memiliki trend yang positif. Dari tahun 1990-2000 luas tambak tumbuh $2,97 \%$ rata-rata per tahun sedangkan pertumbuhan produksi tambak 3,16\%. Sementara itu produktivitas tambak berfluktuasi dari tahun ke tahun tetapi berkisar pada angka 700-800 kg/ha per musim, dengan harga Rp.10125,$/ \mathrm{kg}$. Luas dan produksi tambak tahun 1990-2003 dapat dilihat pada Tabel 1. Sementara untuk produksi ikan bandeng Kabupaten Gresik untuk periode tahun 2004-2005 tersaji pada Tabel 2. dimana untuk ikan bandeng dari tambak air tawar terjadi peningkatan peroduksi $13,5 \%$ (naik 858,15 ton), untuk ikan bandeng dari tambak air payau terjadi penurunan hasil sebesar $1,35 \%$ (220,32 ton).

Tabel 1. Luas Tambak Bersih dan Produksi, 1990-2003

\begin{tabular}{|c|c|c|}
\hline Tahun & Luas (Ha) & Produksi (Ton) \\
\hline 1993 & 432.156 & 355 \\
1994 & 469.839 & 346 \\
1995 & 486.611 & 361 \\
1996 & 492.879 & 404 \\
1997 & 500.468 & 370 \\
1998 & 499.818 & 354 \\
1999 & 523.818 & 413 \\
2000 & 551.778 & 430 \\
2001 & n.a & 455 \\
2002 & n.a & 472 \\
\hline
\end{tabular}

Sumber : DKP Gresik (2002) 
Tabel 2. Data Produksi Ikan Bandeng (Hasil Penangkapan di Tambak) Kabupaten Gresik

\begin{tabular}{|c|l|c|c|c|c|}
\hline \multirow{2}{*}{ No. } & \multirow{2}{*}{ Jenis Ikan } & \multicolumn{2}{|c|}{$\begin{array}{c}\text { Jumlah Produksi } \\
\text { (Ton) }\end{array}$} & \multicolumn{2}{c|}{ Nilai (Rp. 000,-) } \\
\cline { 3 - 6 } & & $\begin{array}{c}\text { Tahun } \\
2004\end{array}$ & $\begin{array}{c}\text { Tahun } \\
2005\end{array}$ & Tahun 2004 & Tahun 2005 \\
\hline 1 & $\begin{array}{l}\text { Tambak Tawar } \\
\text { Bandeng }\end{array}$ & $6.346,3$ & $7.204,45$ & 50.770 .400 & 57.635 .600 \\
\hline 2 & $\begin{array}{l}\text { Tambak Payau } \\
\text { Bandeng }\end{array}$ & $16.219,6$ & $15.999,28$ & 113.537 .200 & 111.994 .960 \\
\hline
\end{tabular}

Sumber: BPS Kabupaten Gresik (2006).

Aspek pemasaran yang mendukung berkembangnya budidaya bandeng tambak adalah kondisi dimana belum pernah terjadi petambak harus menjual bandeng dengan harga yang begitu murah, sehingga menyebabkan kebangkrutan. Aspek konsumsi bandeng adalah sumber protein yang tidak mengandung kolesterol. Beberapa produk olahan bandeng seperti bandeng presto, bandeng asap, otak-otak adalah produk bandeng yang mudah didapat dan dijumpai di supermarket (lihat Tabel 3.).

Bandeng dikonsumsi oleh seluruh golongan masyarakat baik di pedesaan maupun di perkotaan
(Tabel 4.). Konsumsi bandeng penduduk pedesaan lebih rendah dari pada penduduk perkotaan dengan perbandingan 0,884 $\mathrm{kg} / \mathrm{kapita} / \mathrm{tahun}$ dan 1,664 $\mathrm{kg} / \mathrm{kapita} /$ tahun. Hal ini terkait dengan ketersediaan bandeng di daerah perkotaan yang cukup memadai. Daerah produksi bandeng umumnya berada di pantai yang relatif dekat dengan daerah perkotaan sehingga bandeng tersedia dalam jumlah yang cukup. Sementara itu untuk wilayah pedesaan yang jauh dari daerah produksi relatif sulit ditemukan bandeng karena pemasaran bandeng yang masih dalam bentuk segar sangat rawan akan kerusakan. 
Jurnal Teknologi Pangan Vol.2 No.1

November 2011

Tabel 3. Kandungan Protein, Omega-3 dan Lemak per 100 gram Ikan

\begin{tabular}{|l|c|l|c|l|c|}
\hline Jenis Ikan & $\begin{array}{c}\text { Protein } \\
\text { (gram) }\end{array}$ & $\begin{array}{c}\text { Jenis } \\
\text { Ikan }\end{array}$ & $\begin{array}{c}\text { Omega-3 } \\
(\text { gram })\end{array}$ & $\begin{array}{c}\text { Jenis } \\
\text { Ikan }\end{array}$ & $\begin{array}{c}\text { Total } \\
\text { Lemak } \\
\text { (gram) }\end{array}$ \\
\hline Bandeng & 20 & Tuna & 2,1 & Bawal & 9,5 \\
\hline Ikan mas & 16 & Sarden & 1,2 & Kembung & 11,5 \\
\hline Kembung & 22 & Salmon & 1,6 & Tenggiri & 13,9 \\
\hline Sarden & 21 & Makerel & 1,9 & Nilam & 8,2 \\
\hline Pindang & 28 & Hering & 1,2 & Teri & 4,8 \\
\hline Gabus kering & 58 & Teri & 1,4 & Tongkol & 4,9 \\
\hline Ikan asin & 42 & Tongkol & 1,5 & Emas & 5,6 \\
\hline Teri kering & 33 & Tenggiri & 2,6 & & \\
\hline & & Tawes & 1,5 & & \\
\hline
\end{tabular}

Sumber: Khomsan (2004).

Tabel 4. Konsumsi Bandeng Per Kapita per Tahun Berdasar Wilayah Tempat Tinggal

\begin{tabular}{|c|c|c|}
\hline $\begin{array}{c}\text { Golongan Pendapatan } \\
\text { (Rp 000/bulan) }\end{array}$ & Perkotaan & Pedesaan \\
\hline$<40$ & - & - \\
$40-50$ & - & - \\
$60-79$ & - & 0,052 \\
$80-99$ & 0,624 & 0,208 \\
$100-149$ & 0,624 & 0,624 \\
$150-199$ & 1,196 & 1,092 \\
$200-299$ & 1,404 & 1,612 \\
$300-499$ & 2,600 & 1,716 \\
$>500$ & 3,016 & 1,404 \\
\hline Rata-rata & 1,664 & 0,884 \\
\hline
\end{tabular}

Sumber : DKP Grseik (2003)

Makin tinggi pendapatan masyarakat makin tinggi pula tingkat konsumsi akan ikan bandeng. Berdasarkan data tahun
2003 konsumsi protein hewani baru mencapai 11,76 gram/kapita/hari sementara standar yang dianjurkan adalah 15 gram per kapita per hari. 
Berdasarkan Tabel 5. dapat tahun 1994-2003 dapat mencapai dijelaskan bahwa konsumsi $6,33 \%$ rata-rata per tahun. bandeng per kapita per tahun untuk Pertumbuhan tersebut dapat tahun 1996 adalah $0,676 \mathrm{~kg}$, tahun dikatakan cukup tinggi. Volume 1999 adalah $0,52 \mathrm{~kg}$ dan tahun 2003 adalah 1,664 kg. Berdasarkan data-data tersebut maka secara umum dapat dihitung asumsi permintaan akan bandeng adalah sebagai berikut :

1) Tahun 1994-1997 adalah periode sebelum krisis maka tingkat konsumsinya dianggap mengikuti pola konsumsi tahun 1996, artinya kondisi yang stabil selama tahun 1994-1997.

2) Tahun 1998 - 2000 adalah periode krisis sehingga tingkat konsumsi diasumsikan sama dengan tahun krisis yakni konsumsi tahun 1999.

3) Tahun 2001 - 2003 merupakan periode pemulihan, oleh karena itu konsumsi tahun ini diasumsikan sama dengan tingkat konsumsi tahun 2003.

Berdasar asumsi diatas maka perkiraan permintaan bandeng penjualan terjadi peningkatan, dan kondisi tersebut masih dapat ditingkatkan, jika permintaan pasar terus meningkat. Namun demikian yang terjadi saat ini adalah belum tercapainya keseimbangan antara jumlah permintaan pasar dengan produktivitas hasil tambak bandeng, kondisi seperti ini merupakan peluang usaha yang harus segera ditangkap. Kemampuan supply sangat terbatas (ketersediaan bandeng tidak stabil dari tahun ke tahun lihat Tabel 5.), sehingga strategi dan kebijakan sebagai sarana untuk mencapai sasaran usaha belum dapat dilaksanakan sepenuhnya, sehingga pengembangan pasar dengan konsumen barupun belum dapat dilakukan. Padahal seharusnya pada kondisi seperti ini, market modification merupakan strategi yang tepat untuk dijalankan oleh pembudidaya ikan bandeng ataupun produsen bandeng presto. 
Tabel 5. Permintaan Bandeng Nasional, 1994-2003

\begin{tabular}{|c|c|c|c|}
\hline Tahun & Penduduk (000) & $\begin{array}{c}\text { Konsumsi } \\
\text { (Kg/kap) }\end{array}$ & Permintaan (ton) \\
\hline 1994 & 192.216 & 0,676 & 129.938 \\
1995 & 195.283 & 0,676 & 132.011 \\
1996 & 198.342 & 0,676 & 134.079 \\
1997 & 201.020 & 0,676 & 135.889 \\
1998 & 203.735 & 0,520 & 105.942 \\
1999 & 204.784 & 0,520 & 106.487 \\
2000 & 205.843 & 1,196 & 246.188 \\
2001 & 208.621 & 1,196 & 249.510 \\
2002 & 212.003 & 1,196 & 253.555 \\
2003 & 204.783 & 1,196 & 244.920 \\
\hline
\end{tabular}

Sumber: DKP Gresik (2003)

Produsen dalam menghasilkan bandeng presto, otak-otak dan bandeng asap sesuai keinginan pelanggan, maka sejak awal produsen olahan ikan bandeng harus memberikan perhatian lebih mengenai mutu (aman, sehat, cita rasa dsb) bandeng olahan yang dihasilkan. Usaha-usaha mengenai perbaikan kualitas tidak hanya dilakukan saat ada keluhan dari pembeli, namun perbaikan tersebut dilakukan secara terus menerus sesuai dengan harapan dan keinginan sebagian besar pelanggan.

Pada penelitian ini akan menganalisis seberapa besar pengaruh variabel kualitas produk, pelayanan, harga, promosi dan distribusi terhadap kesukaan konsumen dalam membeli produk bandeng presto, dan menentukan pengaruh variabel yang dominan terhadap kesukaan konsumen dalam membeli produk bandeng presto, sehingga dari ketentuan tersebut dapat dibuat saran untuk mendapatkan solusi yang paling tepat dalam menentukan sebuah kebijakan pemasaran bagi produsen produk olahan bandeng, yang pada masa-masa mendatang dapat diterapkan demi pengembangan usaha.

\section{Metode Penelitian}

Berdasarkan data-data penjualan ikan bandeng kabupaten Gresik tahun 2004-2005 Tabel 2., menunjukkan volume penjualan relatif menurun, maka perlu diteliti 
faktor-faktor yang berpengaruh memperdagangkan hasil olahan terhadap kesukaan konsumen untuk ikan bandeng tersebut.

membeli produk bandeng presto. Variabel yang digunakan Penelitian ini dibatasi ruang dalam penelitian ini terdiri dari lingkupnya pada perilaku kesukaan variabel terikat (Y) kesukaan konsumen pada produk bandeng konsumen membeli produk presto Gresik, dimana beberapa bandeng presto dan variabel bebas industri rumah tangga pembuat yang terdiri dari lima variabel yaitu: bandeng presto, otak-otak dan (1) kualitas produk $=\mathrm{X} 1$, (2) bandeng asap menghasilkan dan pelayanan $=\mathrm{X} 2$, (3) harga $=\mathrm{X} 3$, (4) promosi $=\mathrm{X} 4,(5)$ distribusi $=\mathrm{X} 5$. 
Tabel 6. Variabel dan Indikator

\begin{tabular}{|c|c|c|c|}
\hline No. & Variabel & Indikator & Butir Pertanyaan \\
\hline 1 & $\begin{array}{l}\text { Kualitas } \\
\text { produk } \\
(\mathrm{X} 1)\end{array}$ & $\begin{array}{l}\mathrm{X}_{11} \text { Rasa dan aroma } \\
\text { produk } \\
\mathrm{X}_{12} \text { Warna olahan } \\
\text { ikan bandeng } \\
\mathrm{X}_{13} \text { Daya awet }\end{array}$ & $\begin{array}{l}\text { - } \text { Rasa dan aroma sesuai } \\
\text { standar penerimaan } \\
\text { konsumen } \\
\text { - Warna kuning kecoklatan } \\
\text { (hasil pemanasan) } \\
\text { - Lama awet ikan sesuai } \\
\text { standar penerimaan } \\
\text { konsumen }\end{array}$ \\
\hline 2 & $\begin{array}{l}\text { Pelayanan } \\
(\mathrm{X} 2)\end{array}$ & $\begin{array}{l}\mathrm{X}_{21} \text { Pelayanan pra } \\
\text { pembelian } \\
\mathrm{X}_{22} \text { Pelayanan purna } \\
\text { pembelian } \\
\mathrm{X}_{23} \text { Pelayanan } \\
\text { tambahan }\end{array}$ & $\begin{array}{l}\text { - Informasi kualitas, harga dan } \\
\text { delivery order } \\
\text { - Pengembalian produk yang } \\
\text { tidak memenuhi, syarat \& } \\
\text { penggantian } \\
\text { - } \text { Informasi pembayaran } \\
\end{array}$ \\
\hline 3 & $\begin{array}{l}\text { Harga } \\
\text { (X3) }\end{array}$ & $\begin{array}{l}\mathrm{X}_{31} \text { Harga produk } \\
\mathrm{X}_{32} \text { Potongan harga } \\
\mathrm{X}_{33} \text { Syarat } \\
\text { pembayaran }\end{array}$ & $\begin{array}{l}\text { - Harga produk sesuai harga } \\
\text { pasar } \\
\text { - Ada potongan harga } \\
\text { - Syarat potongan harga } \\
\text { - Pembayaran dimuka } \\
\text { - Pembayaran selesai }\end{array}$ \\
\hline 4 & $\begin{array}{l}\text { Promosi } \\
(\mathrm{X} 4)\end{array}$ & $\begin{array}{l}\mathrm{X}_{41} \text { Pameran } \\
\mathrm{X}_{42} \text { Peragaan/demo } \\
\mathrm{X}_{43} \text { Personal selling }\end{array}$ & $\begin{array}{l}\text { - Pameran yang pernah di } \\
\text { dengar konsumen } \\
\text { - Peragaan cara pembuatan } \\
\text { - Informasi produk dari } \\
\text { salesman }\end{array}$ \\
\hline 5 & $\begin{array}{l}\text { Distribusi } \\
\text { (X5) }\end{array}$ & $\begin{array}{l}\mathrm{X}_{51} \text { Ketersediaan } \\
\text { produk } \\
\mathrm{X}_{52} \text { Ketepatan waktu } \\
\mathrm{X}_{53} \text { Penyebaran } \\
\text { macamnya produk }\end{array}$ & $\begin{array}{l}\text { - Produk yang tersedia atau } \\
\text { dari produsen lain } \\
\text { - Penyerahan barang tepat } \\
\text { waktu } \\
\text { - Penyebaran produk di } \\
\text { berbagai wilayah }\end{array}$ \\
\hline
\end{tabular}


Data penelitian meliputi dua jenis yaitu data primer dan sekunder, baik yang bersifat kuantitatif maupun kualitatif. Data primer diperoleh secara langsung melalui wawancara dengan konsumen dan produsen produk bandeng presto di Gresik, yang menjadi sampel dalam penelitian ini, dengan metode purposive sampling. Data sekunder diperoleh melalui studi pustaka literaturliteratur, jurnal, dan hasil penelitian pihak lain yang berkaitan dengan faktor-faktor yang mempengaruhi kesukaan konsumen membeli produk bandeng presto. Disamping itu juga dikumpulkan data dari instansi terkait dengan obyek penelitian, seperti dinas kelautan dan perikanan Kabupaten Gresik.

Populasi penelitian ini adalah konsumen/pembeli produk bandeng presto (bandeng presto, bandeng asap dan otak-otak) di Gresik. Saat dilakukan penelitian ini diambil 97 konsumen yang menjadi pelanggan atau pembeli produk tersebut. Nazir (1988), menyatakan bahwa tidak mungkin seorang peneliti dapat meneliti dan mengobservasi seluruh jumlah obyek yang diteliti sebagai populasi. Oleh karena itu, penelitian akan dilakukan pada sebagaian populasi (sampel). Pengambilan sampel dilakukan dengan cara acak (random sampling) berdasarkan rumusan penentuan sampel sebagai berikut:

$$
N=\frac{N}{N(d)^{2}+1}
$$

Dimana:

$$
\begin{aligned}
& \mathrm{n}=\text { Jumlah sampel } \\
& \mathrm{N}=\text { Ukuran populasi } \\
& \mathrm{d}=\text { Presisi yang ditetapkan } \\
& 1=\text { Angka konstanta }
\end{aligned}
$$

Dengan presisi sebesar 5\% dan tingkat kepercayaan sebesar 95\%, sehingga dalam penelitian tersebut mempunyai ketepatan dan ketelitian standar kesalahan yang rendah. Nilai N (populasi) sebesar 97 konsumen/pembeli untuk menentukan jumlah responden dengan perhitungan sebagai berikut:

$$
\mathrm{N}=\frac{97}{97(0,05)^{2}+1}=78 \text { responden }
$$

Data yang terkumpul, di analisis secara kualitatif, yaitu untuk menjelaskan hubungan antara data yang diperoleh dengan landasan teori. Model analisis yang digunakan adalah model regresi 
liniear berganda dengan menggunakan OLS (Ordinary Least Squares), dengan program SPSS sebagai dasar untuk menganalisis dan membuktikan hipotesis.

\section{Hasil Penelitian}

(1) Variabel Kesukaan Konsumen

Penilaian kesukaan konsumen untuk membeli produk olahan ikan bandeng didasarkan pada faktorfaktor yang terdiri dari 3 hal yaitu: (a) Pengenalan produk; (b) Sering tidaknya menggunakan produk dan (c) Minat membeli produk.
Berdasarkan penelitian terhadap 78 responden atau konsumen terhadap ketiga indikator tersebut dapat dilihat pada Tabel 7.

Sebagian besar variabel memberikan tingkat kesukaan konsumen untuk membeli produk bandeng presto. Ini berarti bahwa faktor pengenalan produk, seringnya menggunakan produk dan minat untuk membeli secara keseluruhan dapat memenuhi harapannya.

Tabel 7. Faktor kesukaan konsumen untuk membeli produk olahan ikan bandeng

\begin{tabular}{|c|c|c|c|c|}
\hline No & Indikator & Jawaban & Jumlah & $\%$ \\
\hline \multirow[t]{4}{*}{1} & Sudah lama & a. Sangat mengenal produk & 8 & 10,26 \\
\hline & mengenal rasa & b. Cukup mengenal produk & 45 & 57,69 \\
\hline & kenikmatan & c. Kurang mengenal produk & 22 & 28,21 \\
\hline & $\begin{array}{l}\text { olahan ikan } \\
\text { bandeng }\end{array}$ & d. Tidak mengenal produk & 3 & 3,84 \\
\hline \multirow[t]{4}{*}{2} & Sudah sering & a. Sering mengkonsumsi & 7 & 8,97 \\
\hline & mengkonsumsi & b. Pernah mengkonsumsi & 48 & 61,54 \\
\hline & produk olahan & c. Jarang mengkonsumsi & 21 & 26,93 \\
\hline & ikan bandeng & $\begin{array}{l}\text { d. Tidak pernah } \\
\text { mengkonsumsi }\end{array}$ & 2 & 2,56 \\
\hline \multirow[t]{4}{*}{3} & Masih & a. Sangat berminat membeli & 14 & 17,95 \\
\hline & berminat/sering & b. Cukup berminat membeli & 56 & 71,79 \\
\hline & ketagihan untuk & c. Kurang & 8 & 10,26 \\
\hline & $\begin{array}{l}\text { membeli olahan } \\
\text { ikan bandeng }\end{array}$ & $\begin{array}{l}\text { membeli } \\
\text { d. Tidak berminat membeli }\end{array}$ & 0 & 0 \\
\hline
\end{tabular}

Sumber data: data primer diolah (2010) 
(2) Variabel atau Faktor Kualitas Produk (X1)

Berdasarkan Tabel 8. tersebut menunjukkan bahwa penilaian responden terhadap item yang terkandung dalam masing-masing indikator untuk variabel kualitas produk yaitu rasa dan aroma yang nikmat sesuai standar kesukaan konsumen, warna bandeng kuningcoklat mengkilap, dan lama daya simpan secara keseluruhan memberikan penilaian yang baik berkisar 53,85\% atau sebanyak 42 responden untuk indikator pemenuhan kesukaan konsumen, $66,67 \%$, dapat dijelaskan juga sebanyak 52 responden menyatakan cukup sesuai kesukaan konsumen mengenai warna produk olahan ikan bandeng $(65,385)$. Mengenai lama simpan produk sekitar 51 responden menyatakan cukup memenuhi harapan konsumen mengenai daya awet olahan ikan bandeng. Jadi tingginya frekuensi responden yang setuju terhadap indikator setiap variabel tersebut menunjukkan bahwa secara keseluruhan, sebagian besar responden menyatakan bahwa kulitas produk yang baik adalah merupakan salah satu faktor konsumen membeli produk tersebut. 
Tabel 8. Tanggapan konsumen terhadap kualitas produk olahan ikan bandeng

\begin{tabular}{|c|c|c|c|c|}
\hline No. & Indikator & Jawaban & Jumlah & $\%$ \\
\hline 1 & $\begin{array}{l}\text { Rasa dan aroma } \\
\text { produk olahan } \\
\text { ikan bandeng } \\
\text { sesuai standar } \\
\text { kesukaan } \\
\text { konsumen }\end{array}$ & $\begin{array}{l}\text { a. Sangat sesuai } \\
\text { kesukaan } \\
\text { b. Cukup sesuai kesukaan } \\
\text { c. Kurang sesuai } \\
\text { kesukaan } \\
\text { d. Tidak sesuai kesukaan }\end{array}$ & $\begin{array}{c}29 \\
42 \\
7 \\
0\end{array}$ & $\begin{array}{c}37,18 \\
53,85 \\
8,97 \\
0\end{array}$ \\
\hline 2 & $\begin{array}{l}\text { Warna produk } \\
\text { olahan ikan } \\
\text { bandeng kuning- } \\
\text { coklat mengkilat } \\
\text { (karamel) }\end{array}$ & $\begin{array}{l}\text { e. Sangat sesuai } \\
\text { kesukaan } \\
\text { f. Cukup sesuai kesukaan } \\
\text { g. Kurang sesuai } \\
\text { kesukaan } \\
\text { h. Tidak sesuai kesukaan }\end{array}$ & $\begin{array}{c}15 \\
52 \\
11 \\
0\end{array}$ & $\begin{array}{c}19,23 \\
66,67 \\
14,10 \\
0\end{array}$ \\
\hline 3 & $\begin{array}{l}\text { Daya awet produk } \\
\text { olahan ikan } \\
\text { bandeng }\end{array}$ & $\begin{array}{l}\text { a. Sangat memenuhi } \\
\text { b. Cukup memenuhi } \\
\text { c. Kurang memenuhi } \\
\text { d. Tidak memenuhi }\end{array}$ & $\begin{array}{c}9 \\
51 \\
13 \\
5\end{array}$ & $\begin{array}{c}11,54 \\
65,38 \\
16,67 \\
6,41\end{array}$ \\
\hline
\end{tabular}

Sumber data: data primer diolah (2010)

(3) Variabel atau Faktor Pelayanan (X2)

Berdasarkan Tabel 9. menunjukkan bahwa penilaian responden terhadap item yang terkandung dalam masing-masing indikator untuk variabel/faktor pelayanan yaitu pemberian informasi kualitas produk, jumlah, harga dan ketepatan pengiriman, pelayanan pembelian produk yang tidak memenuhi syarat dan menggantinya dengan yang memenuhi syarat, serta pemberian pelayanan tambahan seprti informasi cara pembayaran, secara keseluruhan penilaian responden yang baik adalah $47,43 \%$ atau sebanyak 37 responden untuk indikator pemberian informasi; $43,59 \%$ atau sebanyak 34 responden menyatakan cukup baik mengenai pelayanan pengembalian produk yang tidak memenuhi syarat 
dan $53,85 \%$ atau sebanyak 42 bahwa secara keseluruhan, responden menyatakan cukup baik sebagaian besar responden terhadap pemberian pelayanan menyatakan pelayanan pedagang tambahan yang diberikan. Jadi olahan ikan bandeng yang baik tingginya frekuensi responden yang setuju terhadap indikator setiap variabel tersebut menunjukkan merupakan salah satu faktor konsumen membeli produk tersebut.

Tabel 9. Tanggapan konsumen terhadap faktor pelayanan pedagang

\begin{tabular}{|c|l|l|c|c|}
\hline No. & \multicolumn{1}{|c|}{ Indikator } & \multicolumn{1}{|c|}{ Jawaban } & Jumlah & $\%$ \\
\hline 1 & Diberikan informasi & a. Sangat memuaskan & 19 & 24,36 \\
& kualitas produk, & b. Cukup memuaskan & 37 & 47,43 \\
& jumlah, harga dan & c. Kurang memuaskan & 22 & 28,21 \\
& ketepatan pengiriman & d. Tidak memuaskan & 0 & 0 \\
\hline 2 & Pelayanan & a. Sangat baik & 32 & 41,03 \\
& pengembalian produk & b. Cukup baik & 34 & 43,59 \\
& yang tidak memenuhi & c. Kurang baik & 9 & 11,54 \\
& syarat dan & d. Tidak baik & 3 & 3,84 \\
& menggantinya & & & \\
\hline 3 & Pedagang & e. Sangat baik & 7 & 8,98 \\
& memberikan & f. Cukup baik & 42 & 53,85 \\
& pelayanan tambahan & g. Kurang baik & 26 & 33,33 \\
& seperti informasi cara & h. Tidak baik & 3 & 3,84 \\
& pembayaran & & & \\
\hline
\end{tabular}

Sumber data: data primer diolah (2010)

(4) Variabel atau Faktor Harga (X3) Berdasarkan Tabel 10. dapat dijelaskan bahwa penilaian responden terhadap item yang terkandung masing-masing indikator untuk variabel atau faktor harga yaitu harga produk olahan ikan bandeng masih sesuai dengan pasar umumnya. Pemberian potongan harga dan syarat-syarat potongan harga, serta syarat pembayarannya relatif masih diterima oleh konsumen atau pembeli. Secara keseluruhan ratarata memberikan penilaian yang baik yaitu $62,82 \%$ atau sebanyak 49 
responden untuk indikator harga cukup sesuai pasaran, $75,64 \%$ atau sebanyak 59 responden menyatakan pedagang sering memberi potongan harga dan syarat-syarat potongan harga, dan $67,95 \%$ atau sebanyak 53 responden menyatakan syarat pembayaran cukup memenuhi syarat-syarat pembayaran saat ini. Jadi tingginya frekuensi responden yang setuju terhadap indikator setiap variabel tersebut menunjukkan bahwa secara keseluruhan, sebagian besar responden menyatakan harga yang ditetapkan oleh pedagang (produsen) olahan ikan bandeng umumnya masih sesuai dengan harapan konsumen yang merupakan salah satu faktor konsumen membeli produk tersebut.

Tabel 10. Tanggapan konsumen terhadap faktor harga produk olahan ikan bandeng

\begin{tabular}{|c|l|l|c|c|}
\hline No & \multicolumn{1}{|c|}{ Indikator } & \multicolumn{1}{|c|}{ Jawaban } & Jumlah & $\%$ \\
\hline 1 & Harga olahan & a. Sangat sesuai harga pasar & 18 & 23,08 \\
& ikan bandeng & b. Cukup sesuai harga pasar & 49 & 62,82 \\
& sesuai dengan & c. Kurang sesuai harga pasar & 10 & 12,82 \\
& harga pasar & d. Tidak sesuai harga pasar & 1 & 1,28 \\
& umumnya & & & \\
\hline 2 & Pemberian & a. Selalu memberi potongan & 12 & 15,38 \\
& potongan harga & b. Sering memberi potongan & 59 & 75,64 \\
& dan syarat-syarat & c. Jarang memberi potongan & 7 & 8,98 \\
& potongan harga & d. Tidak pernah memberi & 0 & 0 \\
\hline 3 & Syarat & a. Sangat memenuhi & 15 & 19,23 \\
& pembayaran saat & b. Cukup memenuhi & 53 & 67,95 \\
& ini & c. Kurang memenuhi & 9 & 11,54 \\
& & d. Tidak memenuhi & 1 & 1,28 \\
\hline
\end{tabular}

Sumber data: data primer diolah (2010) 
(5) Variabel atau Faktor Promosi (X4)

Berdasarkan Tabel 11. menunjukkan bahwa penilaian responden terhadap item yang terkandung masing-masing indikator untuk variabel atau faktor promosi, yaitu apakah promosi pedagang (produses) olahan ikan bandeng pernah dilakukan dan atau didengar konsumen, apakah produsen pernah menlakukan kunjungan teknis pada pelanggan, dan pernah memberi pelatihan tentang fungsi dan manfaat produk tersebut sebagai sumber gizi. Namun dari Tabel 11. secara keseluruhan rata-rata konsumen memberikan penilaian yang baik yaitu $62,82 \%$ atau sebanyak 49 responden untuk indikator pernah dilakukan kunjungan teknis pada pelanggan. 43,59\% atau sebanyak 34 responden menyatakan promosi atau pameran kurang mudah didengar, sehingga pemberian pelatihan tentang manfaat dan fungsi produk masih kurang, sementara promosi yang pernah didengar hanya sebesar $28,21 \%$ atau sebanyak 22 responden menyatakan setuju.

Tabel 11. Tanggapan konsumen terhadap faktor promosi atau pameran produk

\begin{tabular}{|c|l|l|c|c|}
\hline No & \multicolumn{1}{|c|}{ Indikator } & \multicolumn{1}{|c|}{ Jawaban } & Jumlah & $\%$ \\
\hline 1 & Promosi atau & a. Sangat mudah didengar & 1 & 1,28 \\
& pameran produk di & b. Cukup mudah didengar & 22 & 28,21 \\
& wilayah Kab. & c. Kurang mudah didengar & 34 & 43,59 \\
& Gresik yang pernah & d. Tidak pernah didengar & 21 & 26,92 \\
& di dengar & & & \\
\hline 2 & Pernah dilakukan & a. Selalu dilakukan & 5 & 6,41 \\
& kunjungan teknis ke & b. Sering dilakukan & 49 & 62,82 \\
& pelanggan & c. Jarang dilakukan & 23 & 29,49 \\
& & d. Tidak pernah dilakukan & 1 & 1,28 \\
\hline 3 & Pernah diberikan & e. Selalu dilakukan & 2 & 2,56 \\
& pelatihan tentang & f. Sering dilakukan & 34 & 43,59 \\
& penggunaan produk & g. Jarang dilakukan & 30 & 38,47 \\
& dan & h. Tidak pernah dilakukan & 12 & 15,38 \\
& pengamanannya & \multicolumn{2}{|c}{} \\
\hline
\end{tabular}

Sumber data: data primer diolah (2010) 
Jadi tingginya frekuensi responden yang setuju terhadap indikator setiap variabel tersebut menunjukkan bahwa secara keseluruhan, sebagian besar responden menyatakan bahwa faktor promosi yang dilakukan oleh produsen atau pedagang olahan ikan bandeng membantu konsumen untuk mengambil keputusan membeli produk tersebut.

\section{(6) Variabel Distribusi}

Berdasarkan Tabel

12. dijelaskan bahwa penilaian responden terhadap item yang terkandung dalam masing-masing indikator untuk variabel distribusi yaitu apakah produk selalu tersedia atau jika kurang dapat diambilkan dari perusahaan lain, responden yang menyatakan sangat mudah didapatkan sebesar $24,36 \%$ atau sebanyak 19 responden, yang menyatakan cukup mudah didapatkan sebesar $60,26 \%$ atau sebanyak 47 responden dan yang menyatakan kurang mudah didapatkan hanya sebesar 15,38\% atau sebanyak 12 responden, sementara yang menyatakan tidak mudah adalah nihil. Hal ini mengindikasikan bahwa konsumen sebagian besar menginginkan produk bandeng presto selalu tersedia setiap saat pada waktu dibutuhkan, sehingga hal ini menjadi daya tarik untuk memutuskan membeli produk tersebut. Sementara indikator penyerahan barang yang selalu tepat waktu, responden menyatakan sangat tepat waktu sebesar $15,38 \%$ atau 12 responden, yang menyatakan cukup tepat waktu sebesar 58,97\% atau sebanyak 46 responden dan yang menyatakan kurang tepat waktu hanya sebesar $25,65 \%$ atau sebanyak 20 responden, sementara yang menyatakan tidak tepat waktu adalah nihil. Hal ini mengindikasikan bahwa konsumen sebagian besar menginginkan produk olahan ikan bandeng pada saat penyerahan barang selalu tepat waktu menjadi daya tarik untuk memutuskan membeli produk tersebut. 
Tabel 12. Tanggapan konsumen terhadap faktor distribusi produk

\begin{tabular}{|c|l|l|c|c|}
\hline No & \multicolumn{1}{|c|}{ Indikator } & \multicolumn{1}{|c|}{ Jawaban } & Jumlah & $\%$ \\
\hline 1 & Produk selalu & a. Sangat mudah didapatkan & 19 & 24,36 \\
& tersedia atau jika & b. Cukup mudah didapatkan & 47 & 60,26 \\
& kurang & c. Kurang mudah didapatkan & 12 & 15,38 \\
& diambilkan dari & d. Tidak mudah didapatkan & 0 & 0 \\
& perusahaan lain. & & & \\
\hline 2 & Penyerahan & a. Sangat tepat waktu & 12 & 15,38 \\
& barang selalu & b. Cukup tepat waktu & 46 & 58,97 \\
& tepat waktu & c. Kurang tepat waktu & 20 & 25,65 \\
& & d. Tidak tepat waktu & 0 & 0 \\
\hline 3 & Penyebaran & a. Sangat merata & 9 & 11,54 \\
& macamnya & b. Cukup merata & 18 & 23,08 \\
& produk sudah & c. Kurang merata & 28 & 35,90 \\
& merata di & d. Tidak merata & 23 & 29,48 \\
& berbagai & \multicolumn{3}{|c}{} \\
& wilayah & \multicolumn{3}{|c}{} \\
\hline
\end{tabular}

Sumber data: data primer diolah (2010)

Hal ini mengindikasikan bahwa konsumen sebagian besar menginginkan produk olahan ikan bandeng selalu tersedia setiap saat pada waktu dibutuhkan, sehingga hal ini menjadi daya tarik untuk memutuskan membeli produk tersebut. Sementara indikator penyerahan barang yang selalu tepat waktu, responden menyatakan sangat tepat waktu sebesar 15,38\% atau 12 responden, yang menyatakan cukup tepat waktu sebesar 58,97\% atau sebanyak 46 responden dan yang menyatakan kurang tepat waktu hanya sebesar $25,65 \%$ atau sebanyak 20 responden, sementara yang menyatakan tidak tepat waktu adalah nihil. Hal ini mengindikasikan bahwa konsumen sebagian besar menginginkan produk olahan ikan bandeng pada saat penyerahan barang selalu tepat waktu menjadi daya tarik untuk memutuskan membeli produk tersebut. 


\section{Regresi Linier Berganda}

Model analisis data yang digunakan untuk mengetahui variabel-variabel yang mempengaruhi pengambilan keputusan membeli produk bandeng presto menggunakan regresi linier berganda (multiple regression analysis). Hasil perhitungan, kemudian dimasukkan dalam persamaan diatas, maka didapatkan persamaan regresi sebagai berikut:

$\mathrm{Y}=0,428+0,395 \mathrm{X}_{1}+0,0394 \mathrm{X}_{2}+$ $0,218 \mathrm{X}_{3}+0,143 \mathrm{X}_{4}+0,315 \mathrm{X}_{5}$

Dari persamaan di atas maka dapat dijelaskan sebagai berikut :

1) Konstanta $=0,428$, artinya bahwa bila variabel bebas (kualitas produk, pelayanan, harga, promosi dan distribusi) $=$ 0, maka akan menimbulkan pengaruh pada konsumen untuk mengambil keputusan membeli produk olahan ikan bandeng sebesar 0,428.

2) Koefisien regresi untuk variabel kualitas produk (X1) adalah 0,395, maka hal ini mengakibatkan pengaruh kepada konsumen untuk mengambil keputusan membeli produk olahan ikan bandeng, dengan syarat variabel bebas (pelayanan, harga, promosi dan distribusi $)=$ konstan. Hal ini terjadi karena kualitas produk olahan ikan bandeng umumnya sudah dikenal di masyarakat luas, sehingga dapat diambil kesimpulan bahwa kualitas produk sangat mempengaruhi pengambilan keputusan konsumen untuk menggunakan produk olahan ikan bandeng.

3) Koefisien regresi untuk variabel pelayanan (X2) adalah 0,039 dapat diartikan bahwa setiap kenaikan sebesar 0,039, maka mengakibatkan pengaruh kepada konsumen untuk mengambil keputusan membeli produk olahan ikan bandeng, dengan syarat variabel bebas (kualitas produk, harga, promosi dan distribusi) = konstan. Hal ini terjadi karena pelayanan merupakan salah satu bentuk layanan jasa kepada pembeli, sehingga dapat diambil kesimpulan bahwa pelayanan sangat mempengaruhi pengambilan keputusan konsumen untuk membeli produk olahan ikan bandeng.

4) Koefisien regresi untuk variabel harga (X3) adalah 0,218 dapat diartikan bahwa setiap kenaikan sebesar $\quad 0,218 \quad$ maka 
mengakibatkan pengaruh kepada konsumen untuk mengambil keputusan membeli produk olahan ikan bandeng, dengan syarat variabel bebas (kualitas produk, pelayanan, promosi dan distribusi) = konstan. Hal ini terjadi karena harga yang ditetapkan cukup kompetitif dan sesuai dengan harga pasar pada umumnya, sehingga dapat diambil kesimpulan bahwa harga sangat mempengaruhi pengambilan keputusan konsumen untuk membeli produk olahan ikan bandeng.

5) Koefisien regresi untuk variabel promosi (X4) adalah 0,143 dapat diartikan bahwa setiap kenaikan sebesar 0,143 maka mengakibatkan pengaruh kepada konsumen untuk mengambil keputusan membeli produk olahan ikan bandeng, dengan syarat variabel bebas (kualitas produk, harga, harga dan distribusi) $=$ konstan. Hal ini terjadi karena faktor promosi merupakan faktor yang paling penting untuk dipertimbangkan konsumen dalam mengambil keputusan membeli produk olahan ikan bandeng, sehingga dapat diambil kesimpulan bahwa promosi atau pameran sangat mempengaruhi pengambilan keputusan konsumen untuk membeli produk olahan ikan bandeng.

6) Koefisien regresi untuk variabel distribusi (X5) adalah 0,315 dapat diartikan bahwa setiap kenaikan sebesar 0,315, maka mengakibatkan pengaruh kepada konsumen untuk mengambil keputusan membeli produk olahan ikan bandeng, dengan syarat variabel bebas (kualitas produk, pelayanan, harga, dan promosi) = konstan Hal ini terjadi karena faktor distribusi merupakan faktor penting yang berhubungan dengan ketersediaan produk pada saat dibutuhkan yang dipertimbangkan konsumen, sehingga dapat diambil kesimpulan bahwa pelayanan sangat mempengaruhi kesukaan konsumen untuk membeli produk olahan ikan bandeng.

\section{Pembuktian Hipotesis}

(1) Uji Hipotesis Koefisien Regresi Linier Berganda Secara Bersama-sama (Uji F). Pengujian hipotesis dimaksudkan untukmengatahui pengaruh variabel bebas (X) secara bersama-sama terhadap keputusan konsumen 
membeli produk olahan ikan bandeng (Y) dengan menggunakan uji $\mathrm{F}$ dengan taraf keyakinan 95\%, adapun kriteria pengambilan keputusan adalah dengan membandingkan nilai $\mathrm{F}_{\text {sig }}$ dengan nilai $\alpha$. Jika nilai $F_{\text {sig }} \leq 0,05$ maka menolak Ho dan menerima Ha yang berarti bahwa variabel kualitas produk, pelayanan, harga, promosi dan distribusi berpengaruh secara signifikan. Jika nilai $\mathrm{F}_{\text {sig }}>0,05$ maka menerima Ho yang berarti variabel kualitas produk, pelayanan, harga, promosi dan distribusi tidak berpengaruh secara signifikan. Hasil perhitungan uji $F$ dalam penelitian tersebut disajikan pada Tabel 13.

Berdasarkan Tabel 13. diketahui bahwa nilai $\mathrm{F}_{\text {sig }}$ sebesar $0,018<$ nilai $\alpha(0,05)$ berada pada daerah menolak Ho dan menerima Ha yang berarti bahwa variabelvariabel kualitas produk, pelayanan, harga, promosi dan distribusi berpengaruh secara signifikan. Untuk mengetahui apakah seluruh variabel bebas $(\mathrm{X})$ secara bersamasama berpengaruh terhadap pengambilan keputusan konsumen membeli produk olahan ikan bandeng (Y), dilakukan pengujian koefisiensi regresi secara bersamasama (uji F) dengan cara sebagai berikut (Adiningsih, 1993:273):

$$
N=\frac{\mathrm{R}^{2} / \mathrm{K}}{\left(1-\mathrm{R}^{2}\right) /(\mathrm{N}-\mathrm{K}-1)}
$$

dimana:

$\mathrm{F}=$ Koefisien $\mathrm{F}$ hitung

$\mathrm{R}^{2}=$ Koefisien determinasi

$\mathrm{N}=$ Jumlah sampel

$\mathrm{K}=$ Jumlah variabel bebas

Pada Tabel 13. dapat dilihat hasil perhitungan dengan Anova, yang menunjukkan bahwa besarnya nilai $F_{\text {hitung }}$ adalah sebesar 2,927. Sementara bila dilakukan perhitungan secara manual dengan menggunakan rumus tersebut diatas ternyata menunjukkan hasil yang

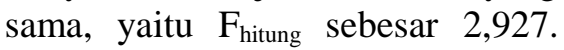
Oleh karenanya dari tabel tersebut besar nilai Sig. $F_{\text {hitung }}=0,018$.

Setelah mengetahui besaran nilai $F$ dan nilai Sig.-nya seperti disebutkan di atas, maka dalam menyimpulkan hipotesisnya dapat dilakukan dengan memperhatikan kaidah-kaidah hipotesis yang menjelaskan hal-hal sebagai berikut:

- Ho : Ha = 0, artinya bahwa variabel-variabel bebas (kualitas produk, pelayanan, 
harga, promosi dan distribusi) secara bersama-sama tidak mempunyai pengaruh terhadap variabel terikat yang berupa keputusan konsumen dalam menentukan pembelian produk olahan ikan bandeng

- Ho : Ha $\neq 0$, artinya bahwa variabel-variabel bebas yang dilakukan penelitian (kualitas produk, pelayanan, harga, promosi dan distribusi) secara bersama-sama mempunyai pengaruh terhadap keputusan konsumen dalam mengambil keputusan membeli produk olahan ikan bandeng

Hasil perhitungan uji $\mathrm{F}$ dalam penelitian ini disajikan dlam Tabel 5.5. Berdasarkan tabel tersebut diketahui bahwa Sig. Fhitung sebesar $0,018<$ nilai $\alpha(0,05)$ berada didaerah menolak Ho dan menerima Ha, yang berarti bahwa variabel kualitas produk, pelayanan, harga, promosi dan distribusi berpengaruh secara signifikan. Mengacu penjelasan tersebut dapat dikatakan bahwa hipotesis yang menyatakan bahwa variabel kualitas produk, pelayanan, harga, promosi dan distribusi berpengaruh signifikan terhadap pengambilan keputusan konsumen dalam membeli produk olahan ikan bandeng diterima. Besarnya pengaruh kelima variabel bebas tersebut dapat diketahui dari besarnya nilai $\mathrm{R}$ square, yang tersaji pada Tabel 13.

Tabel 13. Hasil Perhitungan Koefisiensi Regresi Linier Berganda Secara Bersama-sama (Uji F)

\begin{tabular}{|l|r|r|r|r|c|}
\hline \multicolumn{1}{|c|}{ Model } & \multicolumn{1}{c|}{$\begin{array}{c}\text { Sum of } \\
\text { Squares }\end{array}$} & \multicolumn{1}{c|}{ df } & $\begin{array}{c}\text { Mean } \\
\text { Squares }\end{array}$ & F & Sig \\
\hline Regression & 24.290 & 5 & 2.927 & 2.927 & $0.018^{\mathrm{a}}$ \\
Residual & 119.505 & 72 & & & \\
Total & 143.795 & 77 & & & \\
\hline
\end{tabular}

a. Predictors: (Constant), place, harga, kualitas produk, pelayanan, promosi b. Dependent variable: Keputusan membeli

Sumber data: Hasil Pengolahan Analisis Data dan Pengujian Hipotesis 
Tabel 14. Hasil Uji Hipotesis Koefisien Regresi Linier Berganda (Uji F).

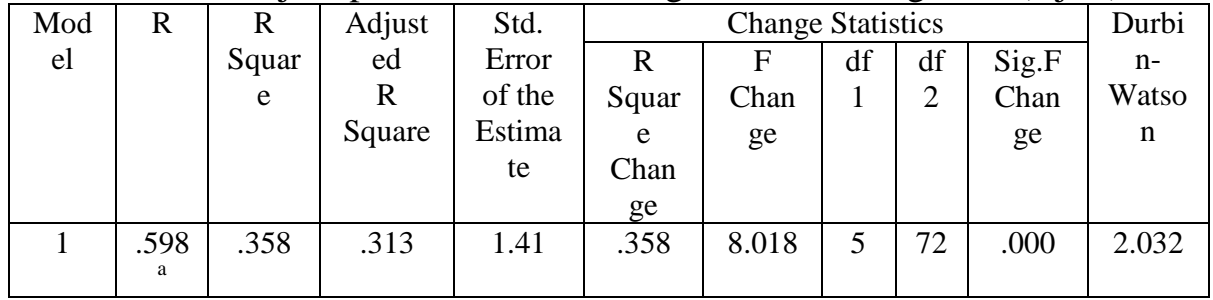

a. Predictors: (Constant), place, harga, kualitas produk, pelayanan, promosi b. Dependent variable: Keputusan membeli

Hasil uji hipotesis koefisien regresi linier berganda (Uji F), yakni sebesar $59,8 \%$. Ini berarti bahwa kelima variabel bebas yang dianalis tersebut secara bersamasama memberikan kontribusi 59,8\% terhadap pengambilan keputusan konsumen dalam membeli produk olahan ikan bandeng, sementara selebihnya $40,2 \%$ dipengaruhi oleh variabel lain yang tidak dijelaskan dalam model.

Dari penjelasan tersebut, dapat disimpulkan bahwa secara bersamasama variabel bebas mempunyai pengaruh yang signifikan terhadap variabel tergantung, dengan demikian dapat dikatakan bahwa hipotesis yang menyatakan bahwa variabel kualitas produk, pelayanan, harga, promosi dan distribusi berpengaruh secara signifikan terhadap pengambilan keputusan konsumen dalam membeli produk olahan ikan bandeng diterima.

(2) Uji Hipotesis Koefisien Korelasi Berganda Secara Parsial (Uji t)

Uji $t$ digunakan untuk mengetahui pengaruh variabelvariabel bebas terhadap variabel tergantung secara parsial. Pengujian dilakukan dengan menggunakan taraf signifikasi 95\%. Kriteria pengujian adalah dengan membandingkan nilai $t_{\text {sig }}$ dengan nilai $\alpha$ berarti terdapat pengaruh secara signifikan secara parsial antar variabel bebas terhadap variabel tergantung. Apabila nilai $\mathrm{t}_{\text {sig }}>$ nilai $\alpha$ secara parsial tidak mempunyai pengaruh secara signifikan antar variabel bebas terhadap variabel tergantung. Hasil perhitungan uji t dapat dilihat pada Tabel 15. yaitu sebagai berikut. 
Tabel 15. Hasil Uji Statistik Koefisien Regresi Linier Berganda (Uji t)

\begin{tabular}{|c|c|c|c|c|c|c|c|c|c|c|}
\hline \multirow[t]{2}{*}{ Model } & \multicolumn{2}{|c|}{ Unstandardized } & $\begin{array}{c}\text { Stdized } \\
\text { Coefisien }\end{array}$ & \multirow[t]{2}{*}{$\mathrm{t}$} & \multirow[t]{2}{*}{ Sig } & \multicolumn{3}{|c|}{ Correlations } & \multicolumn{2}{|c|}{$\begin{array}{c}\text { Collinearity } \\
\text { statistics }\end{array}$} \\
\hline & B & $\begin{array}{c}\text { Std } \\
\text { error }\end{array}$ & Beta & & & $\begin{array}{l}\text { Zero } \\
\text { order }\end{array}$ & Partial & Part & $\begin{array}{l}\text { Toler } \\
\text { ance }\end{array}$ & VIF \\
\hline Constant & .428 & 2.345 & & .182 & .856 & & & & & \\
\hline Kualitas & .395 & 199 & .224 & 1.981 & .051 & .287 & .227 & .213 & .905 & 1.105 \\
\hline produk & $-3.94 \mathrm{E}-02$ & .161 & -.028 & -.245 & .808 & .029 & -.026 & -.026 & .894 & 1.119 \\
\hline Pelayanan & .218 & 177 & .142 & 1.232 & .222 & .169 & .144 & .132 & .871 & 1.149 \\
\hline Harga & .143 & .185 & .088 & .769 & .444 & .133 & .090 & .083 & .885 & 1.130 \\
\hline Promosi & .315 & 136 & .256 & 2.318 & .023 & .280 & .264 & .249 & .943 & 1.061 \\
\hline $\begin{array}{l}\text { Place/ } \\
\text { tempat }\end{array}$ & & & & & & & & & & \\
\hline
\end{tabular}

a. Dependent variable : Keputusan membeli

Berdasarkan Tabel 15. di atas, diketahui bahwa nilai $t_{\text {sig }}$ masingmasing variabel adalah sebagai berikut: $X_{1}=0,051 ; X_{2}=0,808 ; X_{3}$ $=0,222 ; X_{4}=0,444 ; X_{5}=0,023$. Berdasarkan nilai $\mathrm{t}_{\text {sig }}$ masingmasing variabel bebas diketahui bahwa semua variabel yang diteliti mempunyai pengaruh yang signifikan, dimana nilai $t_{\text {sig }}$ dari kelima variabel bebas < nilai $\alpha$, sehingga dapat disusun persamaan regresi linier berganda untuk variabel-variabel yang mempengaruhi pengambilan keputusan konsumen dalam membeli produk olahan ikan bandeng sebagai berikut:

$\mathrm{Y}=0,428+0,395 \mathrm{X}_{1}+0,0394 \mathrm{X}_{2}+$ $0,218 \mathrm{X}_{3}+0,143 \mathrm{X}_{4}+0,315 \mathrm{X}_{5}$
Pada Tabel 15. dapat dilihat dari semua variabel bebas secara parsial nilai probabilitas (lihat kolom sig) lebih kecil dibandingkan dengan 5\%, ini berarti bahwa semua variabel bebas secara parsial mempunyai pengaruh yang signifikan terhadap pengambilan keputusan konsumen dalam pengambilan keputusan membeli produk olahan ikan bandeng. Untuk mengetahui seberapa besar pengaruhnya masing-masing variabel bebas $(\mathrm{X})$ terhadap variabel tergantung $(\mathrm{Y})$, maka lihat kolom Correlation partial, yaitu $\mathrm{X}_{1}$ $=0,227 ; X_{2}=-0,026 ; X_{3}=0,144$; $X_{4}=0,090$ dan $X_{5}=0,264$. Hal ini dapat diartikan bahwa untuk mengetahui besarnya pengaruh dan pengaruh yang paling dominan dapat dilihat dari nilai koefisien determinasi parsial seperti tampak dari variabel $\mathrm{X}_{5} \quad$ (distribusi) mempunyai pengaruh paling besar 
dan dapat dikatakan dominan dengan nilai determinasi sebesar 0,264 . Untuk mengetahui besarnya pengaruh variabel kualitas produk, pelayanan, harga, promosi dan distribusi secara bersama-sama terhadap pengambilan keputusan konsumen membeli produk olahan ikan bandeng, maka digunakan analisis koefisien determinasi berganda. Dengan mengacu hasil perhitungan yang ditunjukkan pada Tabel 5.6. di atas, maka diketahui bahwa hasil koefisien determinasi berganda adalah sebesar $\mathrm{R}^{2}=$ 0,598 .

\section{Pembahasan}

Hasil penelitian menunjukkan bahwa terdapat 5 variabel dengan 15 indikator yang mempengaruhi keputusan konsumen produk olahan ikan Bandeng. Kelima variabel tersebut adalah faktor kualitas produk, faktor pelayanan, faktor harga, faktor promosi, dan faktor distribusi. Dari hasil perhitungan analisis regresi berganda secara serentak atau simultan menunjukkan bahwa koefisien regresi untuk variabel kualitas produk (X1) adalah 0,395, dapat diartikan bahwa setiap kenaikan sebesar 0,395 maka mengakibatkan pengaruh kepada konsumen untuk mengambil keputusan embeli produk olahan ikan Bandeng, sementara koefisien regresi untuk variabel pelayanan (X2) adalah 0,039 artinya bahwa setiap kenaikan sebesar 0,039 maka mengakibatkan pengaruh kepada konsumen untuk mengambil keputusan membeli produk olahan ikan Bandeng. Untuk koefisien regresi variabel harga (X3) adalah 0,218 dapat diartikan bahwa setiap kenaikan sebesar 0,218 maka mengakibatkan pengaruh kepada konsumen untuk mengambil keputusan membeli produk olahan ikan Bandeng, sementara koefisien regresi untuk variabel promosi (X4) adalah 0,143 dapat diartikan bahwa setiap kenaikan sebesar 0,143 maka mengakibatkan pengaruh kepada konsumen untuk mengambil keputusan membeli produk olahan ikan Bandeng, dan koefisien regresi untuk variabel distribusi (X5) adlah 0,315 dapat diartikan bahwa setiap kenaikan sebesar 0,315 maka mengakibatkan pengaruh kepada konsumen untuk mengambil keputusan membeli produk olahan ikan Bandeng. Oleh karena itu hipotesa pertama bahwa variabelvariabel bebas yaitu kualitas produk, pelayanan, harga, promosi, dan distribusi secara bersama-sama mempunyai pengaruh terhadap keputusan konsumen dalam 
membeli produk olahan ikan Bandeng dari Kecamatan Cerme Kabupaten Gresik dapat diterima.

Hasil analisis regresi berganda secara partial menunjukkan bahwa masing-masing variabel mempunyai faktor koefisien regresi sebesar $\mathrm{X}_{1}$ (kualitas produk) = 0,227 ; variabel $X_{2}$ (pelayanan $)=-$ 0,026 ; variabel $X_{3}($ harga $)=0,144$; variabel $X_{4}($ promosi $)=0,090$ dan variabel $\mathrm{X}_{5}$ (distribusi) $=0,264$. Hipotesa kedua menunjukkan bahwa variabel-variabel bebas antara lain kualitas produk, pelayanan, harga, promosi dan distribusi secara partial mempunyai pengaruh terhadap keputusan konsumen dalam membeli produk olahan ikan Bandeng dapat diterima. Dari faktor-faktor tersebut diatas, faktor yang dominan mempengaruhi konsumen dalam mengambil keputusan untuk membeli produk olahan ikan Bandeng adalah faktor distribusi yaitu 0,264 atau $26,4 \%$, disusul peringkat berikutnya adalah faktor kualitas produk sebesar 0,227 atau $22,7 \%$.

Mengingat produk bandeng (bandeng presto, bandeng asap, ataupun otak-otak ikan bandeng) adalah produk yang siap konsumsi, bisa dinikmati dan diperoleh kapan saja (tidak tergantung musim), serta dari segi daya awet tentunya cepat rusak, maka kecepatan dan cara pengiriman yang benar adalah merupakan pertimbangan konsumen dalam memutuskan untuk membeli produk olahan ikan Bandeng. Pertimbangan lain yang perlu menjadi perhatian konsumen adalah kualitas produk, dimana faktor ini menjadi pertimbangan yang dominan dalam mengambil keputusan untuk membeli produk olahan ikan Bandeng. Faktor kualitas menentukan dalam mengambil keputusan untuk membeli produk olahan ikan Bandeng, karena kualitas produk berpengaruh sangat signifikan terhadap kesukaan konsumen untuk membeli kembali terhadap produk olahan ikan Bandeng. Sementara faktor-faktor lain yaitu harga, pelayanan dan promosi meskipun pengaruhnya kurang kuat, tetapi tetap saja memberikan kontribusi kepada konsumen dalam pengambilan keputusan untuk membeli produk olahan ikan Bandeng.

\section{Kesimpulan}

Besarnya pengaruh variabel terhadap kesukaan konsumen dalam membeli produk bandeng presto adalah kualitas produk sebesar 0,227, pelayanan $-0,026$, harga 
0,144, promosi 0,090 dan distribusi sebesar 0,264. Pengaruh variabel yang paling dominan terhadap kesukaan konsumen dalam membeli produk bandeng presto adalah distribusi sebesar 0,264 $(26,4 \%)$, dan peringkat berikutnya variabel kualitas produk 0,227 $(22,7 \%)$.

\section{Saran}

1) Mengingat faktor distribusi merupakan variabel yang dominan mempengaruhi kesukaan konsumen dalam membeli produk bendeng presto, maka disarankan agar kecepatan dan cara pengiriman yang benar, sehingga produk bandeng presto sampai ke tingkat konsumen, dengan kondisi kualitas yang masih sesuai standar.

2) Kepada peneliti lain yang berminat untuk mengembangkan studi ini disarankan untuk memperdalam kajian dengan melanjutkan menggunakan variabel lainnya selain kelima variabel- tersebut diatas, sehingga akan memberikan gambaran yang lebih mendalam tentang kajian yang akan dibahas selanjutnya.

\section{DAFTAR PUSTAKA}

Adiningsih, S., 1993. Statistik. PT. BPFE. Yoyakarta

Badan Pusat Statistik Propinsi Jawa Timur, 2003. Data Statistik Perikanan dan Kelautan Propinsi Jawa Timur. Surabaya

Badan Pusat Statistik Kabupaten Gresik, 2006. Data Statistik Perikanan dan Kelautan Kabupaten Gresik

Co Fish Project, 2004. Teknologi Pengolahan Bandeng Presto. Pelatihan Mata Pencaharian Alternatif Bengkalis, 27 Februari 2004. Bagian Proyek Pembangunan Masyarakat Pantai dan Pengelolaan Sumberdaya Perikanan Bengkalis. Hal. 1-8

Dinas Kelautan dan Perikanan Gresik, 2002. Data Statistik Kelautan dan Perikanan Kabupaten Gresik

Dinas Kelautan dan Perikanan Gresik, 2003. Data Statistik Kelautan dan Perikanan Kabupaten Gresik

Khomsan, A., 2004. Peranan

Pangan dan Gizi untuk Kualitas Hidup. Penerbit Grasindo. Jakarta 
Nazir., 1988. Metode Penelitian.

Cetakan Ketiga. Ghalia Indonesia. Jakarta

Susanto, E., 2010. Pengolahan Bandeng (Chanos chanos Fork.) Duri Lunak. Program Penyuluhan Bagi
Masyarakat Pesisir di Kabupaten Batang 27-28 Juli 2010. Program Studi teknologi Hasil Perikanan Universitas Diponegoro Semarang. Hal. 3-19 